\title{
Preserving the unpreservable: a lost world rediscovered at Christian Malford
}

\author{
Philip R. Wilby ${ }^{1}$, Keith Duff ${ }^{2}$, Kevin Page $^{3}$ \& Susan Martin ${ }^{1}$ \\ ${ }^{1}$ British Geological Survey, Keyworth, Nottingham, NG12 5GG, UK. \\ p.wilby@bgs.ac.uk; smart@bgs.ac.uk \\ ${ }^{2}$ Department of Geology, University of Leicester, Bennett Building, University Road, \\ Leicester, LE1 7RH, UK. kld17@leicester.ac.uk \\ ${ }^{3}$ School of Earth, Ocean and Environmental Sciences, University of Plymouth, Drake \\ Circus, Plymouth, PL4 8AA, UK. kevin.page@plymouth.ac.uk
}

The small village of Christian Malford, Wiltshire (UK) is known to palaeontologists the world over because of the chance discovery of an astonishing fossil bonanza in the mid $19^{\text {th }}$ century. Pits in the Jurassic Oxford Clay yielded thousands of specimens of exquisitely preserved ammonites, fish and crustaceans, but became most famous for 'squid' with fossilized soft-parts. The precise location of the find has remained obscure, until now, and a new attempt is underway to understand the ancient environment that triggered this unusual preservation.

Though soft-bodied organisms (e.g. worms and jellyfish) probably dominated most ancient marine ecosystems, as they do now, they are rarely encountered in the fossil record. This is not surprising because soft-tissues generally decompose before the normal processes of fossilization take effect. Consequently, our view of ancient life is heavily biased towards animals that possessed decay-resistant hard-parts, such as bones, teeth or shells. Fortunately, however, a handful of exceptionally well preserved fossil biotas exist, such as the celebrated Burgess Shale, in which the normal processes of decay appear to have been circumvented and traces of soft anatomy (e.g. gut, muscle, eyes) are still present. These so-called Fossil Lagerstätten provide a much clearer picture of ancient ecosystems, and represent critical points of reference against which the 'normal' fossil record may be assessed.

Amongst the most remarkable Lagerstätten are those in which soft-tissues have been replicated in apatite (calcium phosphate). These sometime capture even subcellular details, like cell nuclei and mitochondria, and allow the cryptic anatomy of ancient animals to be dissected as if they were still alive. Indeed, such preservation has helped to resolve some of the classic conundrums of palaeontology, including the affinity of the conodont animal and the likely nature of the earliest metazoans. Surprisingly then, the precise location of one such Jurassic fauna - the Christian Malford Lagerstätte of Wiltshire - has remained obscure since its initial discovery nearly 170 years ago. It yielded an incredible diversity of exquisitely preserved fossils, but became best known for the presence of coleoid cephalopods ('squid') with their entire soft-part anatomy preserved, including the muscular body, the ink sac, the fins and the arms replete with suckers and hooks (Fig. 1). Notably, these were among the first fossils worldwide in which soft-tissues were recognised. For a short time, they also formed the focus for the acrimonious debate between two of the great names of Victorian palaeontology - Gideon A. Mantell and Richard Owen - which had been triggered by disagreement over the nature of the newly discovered dinosaurs.

Unfortunately, many of the best squid specimens from Christian Malford were destroyed in bombing raids on London in 1941. The remainder have been 'improved' 
by preparators and coated in consolidant, rendering them less than ideal for modern enquiry. We describe the quest to relocate this fauna and the preliminary results from a trial excavation.

\section{Lost world}

The Christian Malford Lagerstätte lies within the Peterborough Member of the Oxford Clay Formation (Callovian, Middle Jurassic) (Fig. 2). It was discovered early in the 1840s during the construction of the Great Western Railway and was still being collected up until 1854. Contemporary accounts of the exposure are poor and the distribution of fossils at outcrop is unknown, though according to the amateur palaeontologist Joseph Chaning Pearce writing in 1841 the best preserved fossils came from a $1.8 \mathrm{~m}$ thick part of the succession consisting of 'four or five bands of laminated clay alternating with sandy clay'. Crucially, however, there is no record of whether soft-tissue preservation occurs throughout this entire interval, or only at a single horizon.

The railway cuttings are now degraded and overgrown, and it is not at all certain where the relevant beds crop out. Indeed, there is evidence to suggest that their precise location was kept secret by the early collectors. Recent accounts have proposed that the bulk of the fossils came from a series of temporary excavations, but these occur along a substantial length of track and have all long since flooded. To complicate matters further, there is a dearth of bedrock exposures to refer to and the outcrop of the Oxford Clay cannot be easily differentiated from the underlying Kellaways Clay across the low-lying agricultural land. Fortunately, however, ammonites were collected in large numbers along with the soft-bodied squid and indicate a level within the phaeinum Subzone of the athleta Zone. Their sheer abundance in museum collections invited an attempt to identify the interval in cored boreholes, and in 2006 a programme of percussion drilling was undertaken by the BGS along a $4 \mathrm{~km}$ line adjacent to the railway (Fig. 3). By chance, part of a squid with fossilized soft-parts dropped out of the bottom of the drill barrel at one site, confirming beyond doubt the location of the target biota. However, only in one very small area is the full interval of the phaeinum Subzone present beneath the thick overburden and within the reach of a large excavator.

\section{Breaking new ground}

In October 2007, an area of $32 \mathrm{~m}^{2}$ was excavated to a depth of $5 \mathrm{~m}$, providing access to approximately 240 tonnes of the fossil-bearing mudstone. Almost immediately it became clear that the Christian Malford Lagerstätte differs from most other exceptionally well preserved biotas: the fauna is both diverse and abundant (Fig. 4), and retains soft-parts as well as pristine aragonitic hard-parts. The most conspicuous fossils are the thin-shelled bivalves Bositra and Meleagrinella, and the 'snow-shoe' gastropod Dicroloma. Each of these principally occurs in monospecific or low diversity plasters, probably in part the result of gentle winnowing of the sediment. The lifestyles of the bivalves have been the subject of much debate in the past: they may have either inhabited the surface waters of the Oxford Clay Sea, respectively free-swimming and attached to floating debris, or have lived on the substrate or rooted algae when conditions were amenable. Whatever their ecologies, the conspicuous absence at many levels of indisputably benthic organisms (e.g. scaphopods and the 
oyster Gryphaea), and especially of deep burrowing bivalves, suggests that the sea floor was inhospitable for significant periods to all but the most specialised animals.

Ammonites are common throughout the interval of interest and are overwhelmingly dominated by Kosmoceras phaeinum, the iconic index species used to relocate the fauna. Their shells are invariably crushed, but they retain their original, brilliantly iridescent nacre (see Fig. 4). Some of the putative males also retain the elongate extensions to their body chambers (lappets), but in many cases the shells are damaged. This conflicts with the impression given by the existing museum collections, which we now know to be biased towards only the most perfect material.

Belemnites are rare, but at least 4 of the dozen or so collected preserve their delicate phragmacone, analogous to the 'bone' of the modern cuttlefish. They are believed to have had a nektobenthic lifestyle, and most likely were deterred by the inhospitable bottom water conditions. In contrast, remains of the squid-like animals Belemnotheutis and Mastigophora (for which the locality initially became famous) are preserved in super-abundance relative to other Oxford Clay sites: scores of the former and half a dozen of the latter were collected from the new excavation. Indeed, Mastigophora, and at least two other species of squid, are virtually known only from this locality. No doubt they were more cosmopolitan, but they require exceptional conditions in order to be fossilized. Their abundance implies that they occupied a mid-water niche; a theory that is currently being tested with stable isotope analyses.

Crustaceans comprise another important component of the invertebrate fauna, though they are largely restricted to specific levels which presumably correspond to brief periods of improved environmental conditions. Specimens of one species are particularly well preserved (Fig. 5) and may have occupied elongate burrows which are recorded from the locality for the first time. Similarly, the majority of the dozen or so fish specimens (Fig. 6) that were collected are from a single bed; evidence of larger vertebrates is restricted to an isolated ichthyosaur tooth.

The great surprise from the excavation was the frequency with which soft-tissues occur. They are far more abundant than might reasonably have been anticipated based on the number of specimens (approximately 100-150) that are held in the three most important existing collections (Natural History Museum, London; Bristol City Museum; British Geological Survey, Nottingham). They also occur in a greater range of taxa than hitherto recognised: we collected 2 crustaceans, 3 fish and 8 squid with soft-parts, as well as an isolated ink sac (Fig. 7). In all cases, the soft-parts are preserved with exquisite precision, providing tantalizing glimpses of how they functioned. For example, sections through the body wall of one squid revealed a complex arrangement of muscle fibres, consisting of alternating bands of concentrically- and radially-oriented fibres (Fig. 8). This is reminiscent of the situation seen in modern inshore species, implying that the fossil squid were also agile predators capable of equally powerful bursts of jet-propulsion.

\section{Calamari killing-field}

All the evidence points to an unstable environment in which the bottom waters repeatedly switched between those that could sustain life at the sea bed, albeit impoverished, and those that could not. Fluctuations in oxygen level were most likely the culprit, but life on the bottom may have been made doubly difficult by an unusually 'soupy' substrate. Certainly, attempts at colonising the sediment were repeatedly thwarted, as attested to by the vast numbers of microscopic juvenile bivalves (spat) present at certain levels. By comparison, the overlying water column 
was highly productive and hosted an extremely diverse biota. However, it too was not immune to environmental catastrophe. Extraordinarily high densities of fish at one level, and of squid at others, indicate that the surface waters experienced recurrent episodes of "poisoning”. Such events occur in modern oceans, normally as a result of anoxia, algal blooming or volcanism. Those in the Oxford Clay Sea appear to have decimated a significant area, extending from Christian Malford to Ashton Keynes (20km to the north-east), where identical catastrophes are recorded at a comparable level. They would certainly have choked the water with millions of carcasses of fish and squid.

Modern squid are voracious predators and will take live and dead prey, including individuals of their own species. There is no reason to assume that those in the Oxford Clay acted any differently. Indeed, an unusually high proportion of the squid from Christian Malford (including a newly collected specimen) are preserved clasping other squid or fish in their arms (see Fig. 1). A picture therefore emerges of a predator-trap, in which earlier victims acted as a draw on new shoals of squid entering the area, which themselves became overcome in a perpetual deadly cycle.

\section{Conclusions}

Though the Oxford Clay has a long history of palaeontological enquiry, substantial finds of soft-tissue preservation remain confined to Christian Malford and nearby Ashton Keynes. What, if any, connection the coincident mass killings have to this unusual style of fossilization is currently the subject of investigation. Certainly, the newly acquired material promises to yield important new insights into the depositional environment and the trigger(s) for exceptional preservation, as well as the behaviour, ecology and anatomy of the fauna.

\section{Acknowledgements}

We are grateful to the landowners for kindly granting us access to undertake this work and acknowledge Karen Philbin's assistance with collecting. Steve Thorpe and Ricky Terrington are thanked for their diligent persistence with the exploratory drilling programme, and Mark Woods and Ian Wilkinson (all BGS) for offering helpful comments on an earlier draft of this contribution. The fossils were photographed by Paul Witney (BGS). The work was supported by grants from the Curry Fund of the Geologists’ Association (03/07/D), the British Geological Survey University Funding Initiative (P094) and the Geological Society of London (SW Branch). The article is published with the permission of the Executive Director, British Geological Survey (NERC).

\section{Suggestions for further reading}

Donovan, D.T. \& Crane, M.D. 1992. The type material of the Jurassic cephalopod Belemnotheutis. Palaeontology, v.35, pp273-296.

Doyle, P. \& MacDonald, D.I.M. 1993. Belemnite battlefields. Lethaia, v.26, pp.6580.

Mantell, G.A. 1848. Observations on some belemnites and other fossil remains of Cephalopoda, discovered by Mr. Reginald Neville Mantell in the Oxford Clay near Trowbridge, in Wiltshire. Philosophical Transactions of the Royal Society, v.138, pp.171-182, pls.13-15. 
Martill, D.M. \& Hudson, J.D. (eds.) 1991. Fossils of the Oxford Clay.

Palaeontological Association, Field Guides to Fossils No. 4. The Palaeontological Association, London, 286pp.

Owen, R. 1844. A description of certain belemnites, preserved, with a great proportion of their soft parts, in the Oxford Clay at Christian Malford, Wilts. Philosophical Transactions of the Royal Society, v.125, pp.65-85, pls.2-8.

Pearce, J.C. 1841. On the mouths of ammonites, and on fossils contained in laminated beds of the Oxford Clay, discovered in cutting the Great Western Railway, near Christian Malford in Wiltshire. Proceedings of the Geological Society of London, v.3, pp.592-594.

Tang, C.M. 2002. Oxford Clay: England's Jurassic Marine Park. In: Exceptional Fossil Preservation: a unique view on the evolution of marine life (eds. Bottjer, D.J., Etter, W., Hagadorn, J.W. \& Tang, C.M.). Columbia University Press, New York, 403pp.

Wilby, P.R., Hudson, J.D., Clements, R.G. \& Hollingworth, N.T.J. 2004. Taphonomy and origin of an accumulate of soft-bodied cephalopods in the Oxford Clay Formation (Jurassic, England). Palaeontology, v.47, pp.1159-1180.

Fig. 1. Complete specimen of the largely soft-bodied squid Belemnotheutis clasping a fish (arrowed) in its arms; collected in the mid-nineteenth (NHM 88603).

Fig. 2. Location of the Christian Malford Lagerstätte relative to the crop of the Oxford Clay Formation.

Fig. 3. Perisphinctid ammonite recovered during exploratory drilling.

Fig. 4. Bedding-plane surface strewn with fossils, including: the ammonite $K$. phaeinum, the gastropod Dicroloma (D), coprolites (C), a Belemnotheutis phragmacone (B) and an ammonite jaw (J).

Fig. 5. Exceptionally well preserved shrimp-like crustacean; with explanatory inset.

Fig. 6. Fish with entire soft-part anatomy preserved (cream areas) and with head still concealed beneath sediment. Explanatory inset shows positions of vertebrae, pectoral fins and body outline.

Fig. 7. Cephalopod ink sac and duct with impressions of blood vessels from the formerly enshrouding muscular bag.

Fig. 8. Complex arrangement of radially- (vertical arrows) and concentrically- (angled arrows) oriented muscle fibres in the body wall of a squid; scanning electron microscope image. 

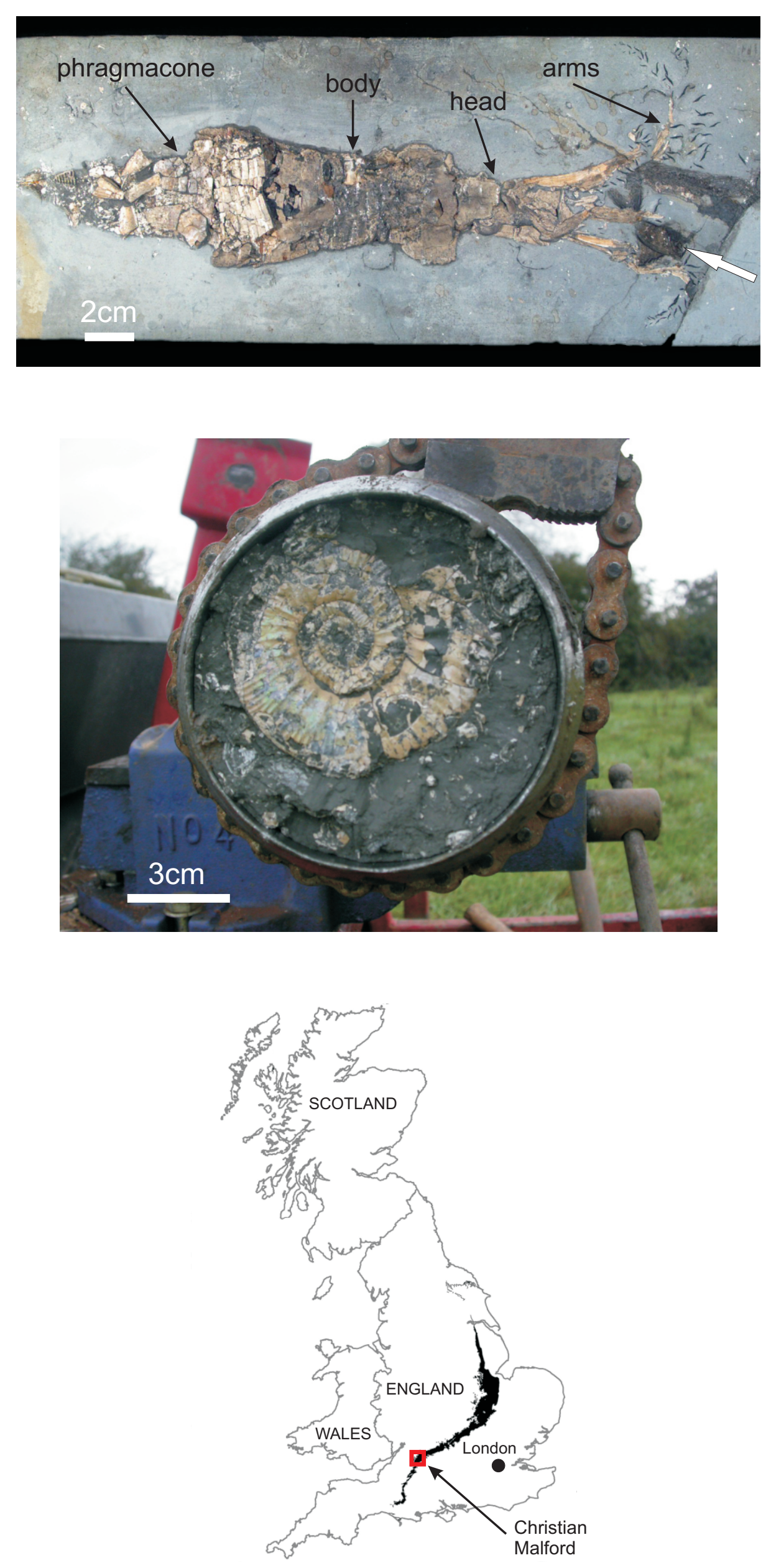

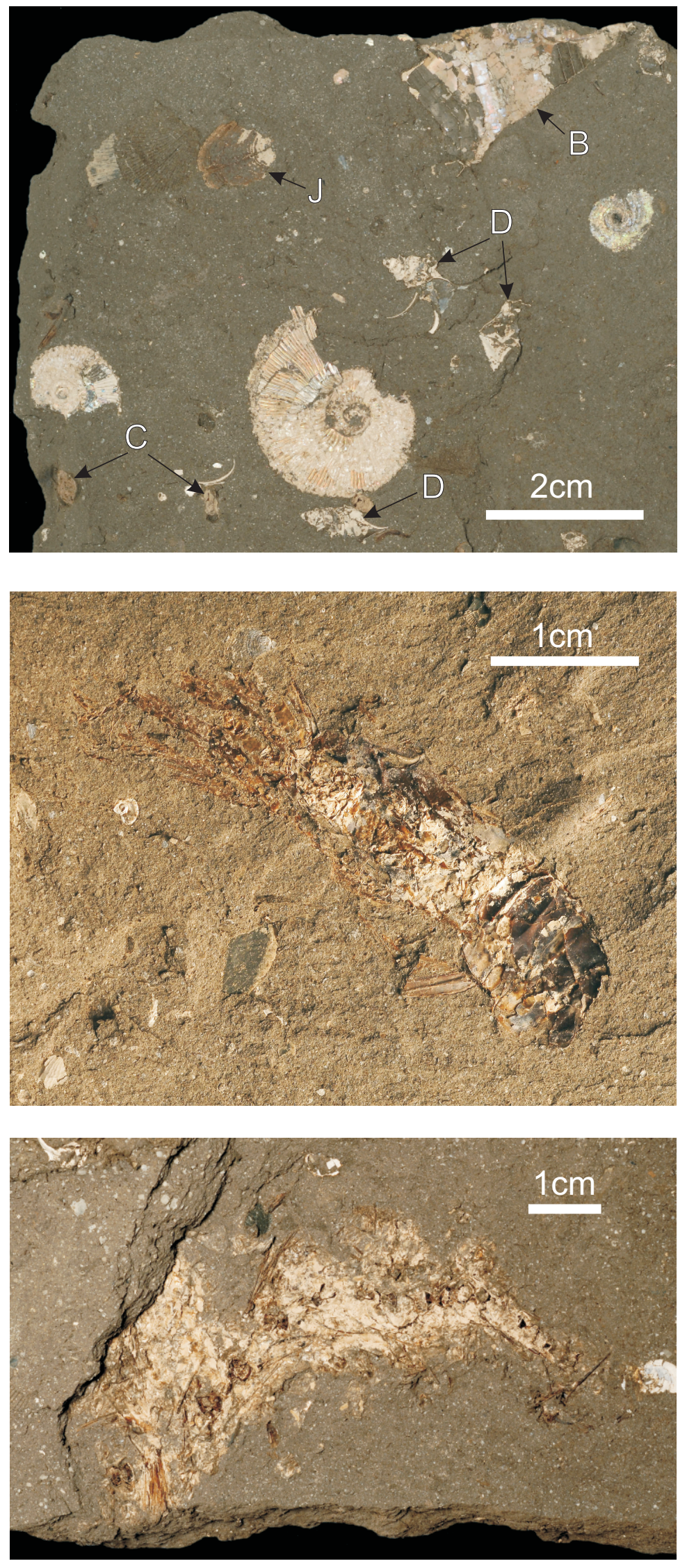

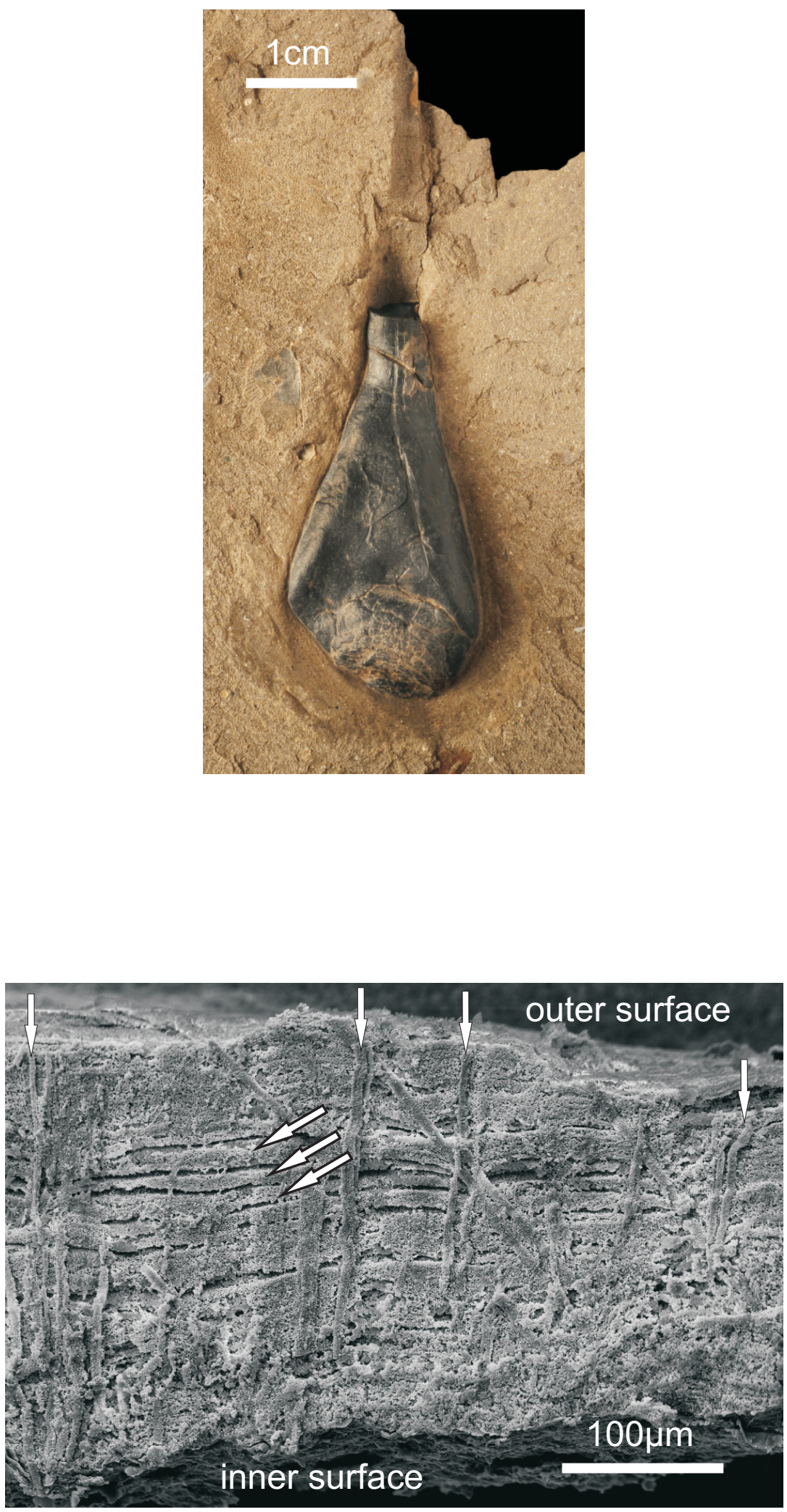